\title{
MINING
}

UDC 622.236.2:622.24

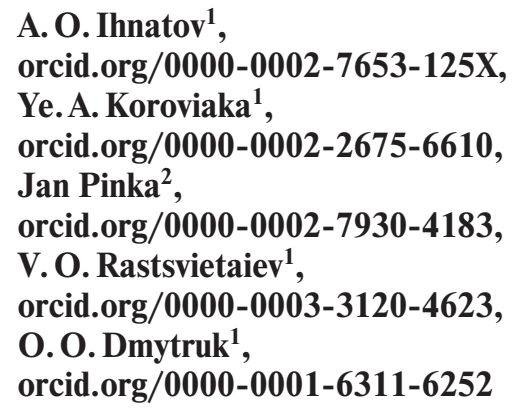

A. O. Ihnatov ${ }^{1}$, orcid.org/0000-0002-7653-125X, Ye. A. Koroviaka ${ }^{1}$, orcid.org/0000-0002-2675-6610, Jan Pinka ${ }^{2}$, orcid.org/0000-0002-7930-4183, V.O. Rastsvietaiev ${ }^{1}$ orcid.org/0000-0003-3120-4623, O.O. Dmytruk ${ }^{1}$, orcid.org/0000-0001-6311-6252

https://doi.org/10.33271/nvngu/2021-1/011

1 - Dnipro University of Technology, Dnipro, Ukraine, e-mail: ignatov.a.a@nmu.one

2 - Technical University of Kosice, Kosice, Slovak Republic, e-mail: jan.pinka@tuke.sk

\section{GEOLOGICAL AND MINING-ENGINEERING PECULIARITIES OF IMPLEMENTATION OF HYDROMECHANICAL DRILLING PRINCIPLES}

Purpose. Substantiation of the design solutions in separate units of the modernized hydromechanical devices and specification of rational technological modes of their operation in specific geological and technical conditions. Proposals on construction of wells by development and introduction of progressive methods and techniques.

Methodology. Analysis of the peculiarities of the modernized hydromechanical drilling devices in terms of rock breaking is performed using modern methods of analytical analysis and experimental research, i. e. by using mathematical and physical modeling; method of modeling and processing of research results in the SolidWorks medium and others; control and measuring tools and materials. The process of solving the problems of optimal planning of the experiment was divided into four stages: development of a planned model; preparation of the necessary initial data; calculation of the model; obtaining and processing of the results. The well rock-breaking processes were modeled on a special-purpose laboratory stand equipped with a measuring and control unit (flow meter, manometer, tachometer, and coordinate spacer).

Findings. The main ways to improve well hydromechanical technologies have been identified. The fundamental principles have been formulated concerning the process of design of such equipment schemes that will combine the most productive and efficient methods of the rock mass operations. A number of factors characteristic of the implementation of well hydromechanical technologies, have been identified, i.e.: rational range of physical properties of rocks according to which proper technical and technological characteristics of the devices are selected; structural use of mechanical rock-breaking organs of the devices; and operating parameters of the drilling process. It has been proved that the developed design schemes of hydromechanical drilling devices, in terms of their optimal technical performance and technological development, can be recommended for their use in the appropriate geological and technical conditions, where the implementation of other methods is inexpedient or limited.

Originality. Formation of the peripheral part of the bottomhole is a subordinate factor determined by the device design; effective profiling is possible only due to the introduction of additional components into the hydromechanical drilling devices, which makes it possible to use certain technological methods.

Practical value. The obtained results of laboratory and analytical studies are basic to design operating parameters of the well deepening processes by using the hydromechanical devices. Data from the study on bottomhole working processes of hydromechanical technologies are the starting point for the substantiation of design and technological parameters of modernized pellet impact devices.

Keywords: hydromechanical drilling, well, washing liquid, rock, pellet impact device, bottomhole

Introduction. Analysis of the problems concerning the development of leading branches of science and production proves the all-round use of innovative methods and technologies $[1,2]$, whose implementation is possible only on the basis of wide generalization and thorough study on primary and secondary scientific-production processes and subsystems $[3,4]$, that finally determines the trajectory and results of human manufacturing activity $[5,6]$.

Current practice of industrial production demonstrates that the improvement of both certain technological processes and the whole technological chains $[7,8]$ should be based on

(C) Ihnatov A. O., Koroviaka Ye.A., Jan Pinka, Rastsvietaiev V. O., Dmytruk O. O., 2021 complex and interrelated approaches to the solution of the problems related to increasing productivity and improving quality of operations $[9,10]$.

The approaches are not the exception for the mining industry, a powerful industry of domestic production that creates the material basis for many other producing operators.

Mode of occurrence of minerals in the earth's interior as well as their quality, reserves, and economic expediency of extraction are defined with the help of mining and exploratory workings and drilling wells [11].

Deposits of coal, iron and manganese ores, numerous deposits of nonferrous metals, being of simple mode of occurrence and expansion, are explored mostly by drilling. Polymetallic ores as well as the ores of rare precious metals are ex- 
plored by drilling in combination with mining and exploratory workings [12].

Drilling is widely used in production to solve numerous problems; it is especially popular in terms of geological surveying, exploratory and field operations as well as during the engineering and geological studies. Progress of the national economy results in the considerable increase in the volumes of well drilling application connected with the exploration and development of solid and liquid (gaseous) mineral deposits. Moreover, growing scopes of hydrotechnical, industrial, and housing construction operations also require rapid increase in the amount of drilling operations and the costs for their performance respectively [11].

Relying on the aforementioned, search for the ways to reduce capital intensity of drilling operations and increase their efficiency is one of the most important problems of the current stage of mining industry development; there is no doubt in the topicality of that problem.

One of the most prospective ways to rationalize the drilling methods and technology is the improvement of the predominant cycle of well construction - breaking of its bottomhole.

A peculiarity of the breaking process in terms of well construction is considerable distancing of a rock-breaking tool from the main drive of a drill rig, resulting in great energy losses during its transferring onto the well bottomhole. That characterizes mostly rotary and spindle drilling. That is the mentioned reason resulted in the origin of drilling methods, which differ in the location of drive motor immediately close to a rock-breaking tool - those methods are called turbine, screwmotor, and electric drilling methods [11].

Construction of a well shaft is not a continuous process. It is accompanied by the operational and forced shutdowns to replace the worn rock-breaking tool among other things. In particular, not mentioning all the features of drillstring tripping, it should be noted that the duration of those operations accounts for $30 \%$ of all the drilling time or even more [13].

The research works dealing with the improvement of well construction process may be divided conventionally into several areas. Among them, there are the following essential ones: rationalization of the industrial organizations, improvement of the power equipment, focus of the facility on the most important operations of a well construction cycle, increasing efficiency of energy consumption and, the topmost area, the development of innovative drilling techniques [1].

Rock breaking while drilling has one more peculiarity, which differentiates this process from the one characteristic for some other industries, - that is compulsory separation of certain rock volume from the mass and its removal to the surface [14].

It has been proved theoretically and experimentally that the directivity of breaking processes within the rock mass is determined by the application of the external forces aimed at overcoming the force of internal bonds within the rock mass and final resulting in its breaking. Along with that, special studies have demonstrated the available close relation between the results of deformational processes and velocities of the applied loads. The latter factor is the reason why numerous innovative techniques of rock breaking, which are based mostly on the intensification of effects of different physical fields and their combined action, have appeared [15].

Thus, there is no doubt that the increasing efficiency of rock breaking while drilling will influence directly or indirectly all other indices of the well construction cycle.

Methods. Since the operation related to the rock breaking on bottomhole was selected as the starting point of the improvement of a complex well construction process, studies by the specialists of the Department of Oil-and-Gas Engineering and Drilling (OGED) of Dnipro University of Technology (DUT) are focused on specification of the fundamental principles of design of such equipment schemes that will implement the most productive and efficient methods of the rock mass operations [16].
Development of a series of principally new models of drillstrings for hydromechanical drilling is the result of thorough analysis and generalization of literature sources as well as practical experience of industrial organizations; the models can be called the devices of combined action. They unite organically rather an efficient method for rock breaking by pellet impacting and a method for processing the peripheral zone of well bottomhole, which is proposed in the work "Petroleum Engineering: Drilling and Well Completions" (Gatlin C.).

The studies concerning the operation of the developed equipment for hydromechanical drilling carried out at the Department of OGED of Dnipro University of Technology [15] have identified numerous effecting factors for the devices. The following factors are the most important ones to be analyzed in the paper: a rational range of physical properties of the rock according to which the technical and technological characteristics of the devices are selected; physical properties of breaking pellets; structural use of mechanical rock-breaking organs of the devices; operating conditions of the drilling process, and so on.

The conducted studies have proved demonstratively the competitiveness of the developed devices for hydromechanical (modernized pellet impact) drilling under the corresponding geological and technical conditions; their use will favor both the improvement of drilling productivity and cutting time for secondary operations.

Research on the operational features of the modernized hydromechanical drilling devices in terms of rock breaking has been performed involving up-to-date methods of analytical analysis and experimental studies, i.e. by the methods of mathematical and physical modeling with the results processing in the SolidWorks medium etc., measuring and control equipment and materials.

The process of solving the problems of optimal planning of the experiment was divided into four stages: development of a planned model; preparation of the necessary initial data; calculation of the model; and obtaining of the results.

The well rock-breaking processes were modeled on a special-purpose laboratory stand equipped with a measuring and control unit (flow meter, manometer, tachometer, and coordinate spacer).

Results. Despite the availability of considerable practical and theoretical experience in the sphere of well construction, constant improvement of its main technological operations and their maintenance is currently the determining factor for organizational scheme of a cycle of mechanical rotary drilling and its main component - rock breaking, there is still an issue of the bottomhole tool life. Due to the considerable influence of the well conditions (rapid abrasive wear of the cutting structure, sign-variable loads, temperature factors, aggressive action of washing liquid, and so on), the indicated parameters are unacceptably low. The indicated factors are also complicated by the fact that the general negative features of rotary mechanical drilling are represented by rather high nonproductive power losses on the way from the surface power equipment to the bottomhole rock-breaking tool $[17,18]$.

The generalized data make it possible to state the following: rock breaking on the bottomhole takes place under conditions of the use of rather insignificant amount of the whole energy balance consumed for well construction; that is the reason why the integral coefficient of efficiency is evaluated only by shares of the whole number.

The represented data became the momentum into the large-scale research works to develop modern progressive drilling methods, which will be characterized by the reducing to minimum or total leveling of the disadvantages peculiar for the technologies of mechanical rotary drilling.

Development of new methods is accompanied by the indepth implementation of the innovative achievements of a considerable range of fundamental and applied sciences.

While the majority of new methods has not fallen outside the limits of theoretical and laboratory studies, a small alterna- 
tive group of so-called physical methods and its bright representative - hydromechanical (pellet impact) technique - is at the stage of commercial implementation and use. Moreover, nowadays its use has proved its efficiency while drilling dry spots of exploratory and, especially, curvilinear intervals of directional wells including the operating ones. Solid studies on that issue are represented in the paper "Pellet impact drilling" (Uvakov A. B.)

In terms of pellet impact drilling, rock is broken by means of contact interaction of a certain number of steel pellets with the well bottomhole. Fig. 1 shows a principle scheme of a hydromechanical pellet impact device and the drilling method.

There are following key components of the designed cutting structure of a hydromechanical drilling device: a metal case 1 , a nozzle of special configuration 2, a chamber to mix the liquid flows 3 (the mentioned elements create somewhat simplified impact apparatus, whose characteristic feature of operating cycle is the injection coefficient determined by the ratio of consumption of injected and operating liquids), breaking pellets 4 , and circular holes 5 .

The device as a complex structure operates as follows. Certain calculated amount of breaking pellets 4 is supplied onto the well bottomhole. Next, a surface pump helps to create the motion of liquid (purifying agent) flow, which is called the operating one, through a circulating channel of a drillstring. Coming out from a nozzle 2 within the downhole interval with the considerable absolute velocity, the flow forms a rarefaction zone; due to that, there is additional suction (injection) of a purifying agent from the well circular channel and the breaking pellets 4 through circulating holes 5 to a mixing chamber 3 . Interaction of the liquid flows in the chamber 3 must definitely have two parallel processes: increase in the pressure indices occurring without the immediate loss of mechanical energy; leveling of absolute velocities of liquids; in this context, consumption of purifying agent in the chamber 3 exceeds significantly the ones in the nozzle 2 [19]. Thus, interactions of the lows of the breaking pellets 4 accelerate up to the considerable velocities and impact the bottomhole. Collision of the pellets 4 with rock mass is accompanied by the deformation processes resulting in rock breaking with different intensity degree. When the impacting is over, pellets and breaking products are lifted caught by the upward liquid flows. As a result of the considerably lower weight, breaking products are taken from the well by the upward flow of washing liquid while pellets and large debris of breaking products are included in the circulation process again.

The most important difference of hydromechanical (pellet impact) drilling comparing to many others is pretty disproportionate rates of load application (with the help of pellets) to the bottomhole rock reaching up to $60 \mathrm{~m} / \mathrm{s}$ and more. However, it is well-known that all the basic physical characteristics used in the design calculations of drilling technology are obtained un-

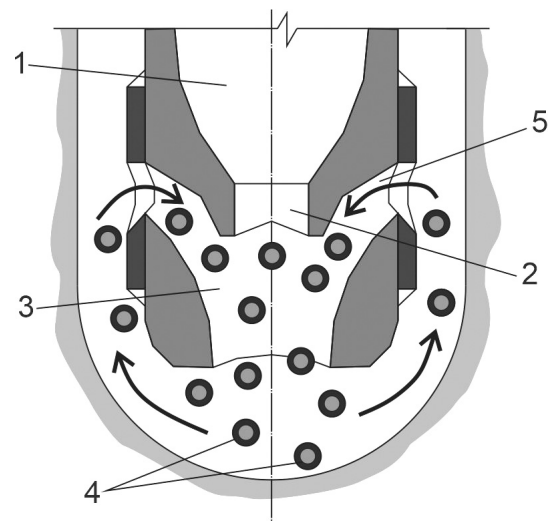

Fig. 1. Structural and logical sequence of the functioning of hydromechanical (pellet impact) drilling facilities [19] der conditions of almost static test of rock that anyway cannot reflect the essence of rock breaking mechanics in terms of the implementation of hydromechanical drilling schemes.

Basing on the identified features of hydromechanical drilling as a method of high dynamicity, specialists of the Department of OGED of Dnipro University of Technology have carried out a series of stand studies whose aim is to obtain the data on the influence of the pellet velocity effect on the development and results of deformation and breaking processes within the rock mass (represented by the elastoplastic rocks). Main results of the studies are given in Table 1.

The data represented in Table 1 tell us about the evident connection between the velocity of load application $v$ and scales of manifestation of rock breaking processes within the rock mass. Along with the increasing $v$, one can observe the decreasing depths and volumes of breaking; in other words, typical elastoplastic rock acquires the properties of brittle rock. That result is somewhat opposite to the one obtained for elastoplastic brittle rocks; along with the increasing $v$, the latter shows the tendency to growing integral index $V_{p}$. As a rockbreaking indentor, the study involved a metal stamp with a rounded tip with the diameter of $2.5 \mathrm{~mm}$ in terms of static load, and metal pellets with the diameter of $d_{k}=5 \mathrm{~mm}$ in terms of dynamic load.

To exclude the effect of anisotropy on the rock breaking indices, the studies similar to the aforementioned ones were carried out in terms of breaking of cement rock, simulating the elastoplastic rock in its properties - aleurolite. Table 2 gives the data of those studies.

The data in Table 2 show that there are no significant changes in the nature of deformation processes for the breaking conditions relative to the homogeneous material under analysis - they are similar to the ones for real rocks. Thus, the

Table 1

Basic dynamic characteristics of rock breaking process by pellet impacting

\begin{tabular}{|c|c|c|c|c|c|}
\hline \multirow[b]{2}{*}{$\begin{array}{c}\text { The analyzed } \\
\text { rock }\end{array}$} & \multirow[b]{2}{*}{ 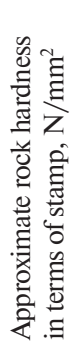 } & \multicolumn{2}{|c|}{$\begin{array}{l}\text { Conditions of } \\
\text { rock breaking }\end{array}$} & \multicolumn{2}{|c|}{$\begin{array}{l}\text { Results of the } \\
\text { rock breaking }\end{array}$} \\
\hline & & 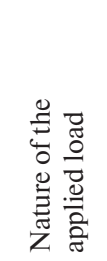 & 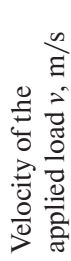 & 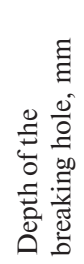 & 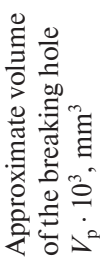 \\
\hline \multirow[t]{3}{*}{ limestone } & 1460 & static & - & \multicolumn{2}{|c|}{$\begin{array}{l}\text { does not result in } \\
\text { typical breaking }\end{array}$} \\
\hline & - & dynamic & 20 & 6.7 & 1.968 \\
\hline & & & 30 & 5.4 & 1.262 \\
\hline
\end{tabular}

Table 2

Basic dynamic characteristics of artificial bottomhole breaking by pellet impacting

\begin{tabular}{|c|c|c|c|c|}
\hline \multirow{2}{*}{ 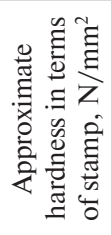 } & \multicolumn{2}{|c|}{ Breaking conditions } & \multicolumn{2}{|c|}{ Results of the breaking process } \\
\hline & 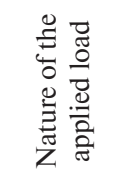 & 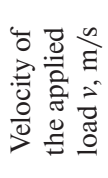 & 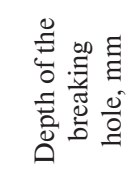 & 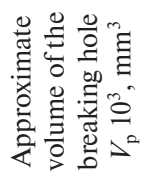 \\
\hline 780 & static & - & \multicolumn{2}{|c|}{$\begin{array}{c}\text { does not result in typical } \\
\text { breaking }\end{array}$} \\
\hline \multirow[t]{2}{*}{-} & \multirow[t]{2}{*}{ dynamic } & 20 & 5.6 & 1.593 \\
\hline & & 30 & 4.8 & 0.962 \\
\hline
\end{tabular}


factor of the available dependence of the properties of elastoplastic rocks on the velocities of load application as well as the manifestation of brittle properties in the mentioned rocks, peculiar for those conditions, may be considered as a proved one.

Basing on the conducted studies, it can be stated that in terms of breaking of elastoplastic rock, one should be stick to relatively slow velocities of load application $v$ as their increase results in the reduced breaking scale.

Speaking about the pellet impact drilling and technical means for its implementation, it is sure that they can be characterized as relatively simple, which is one of the main advantages of that method. The fact that the hydromechanical devices are equipped with free mobile rock-breaking pellets determines a practically unrestricted number of drilling runs, being the main reserve of the productivity increase. A serious organic disadvantage of the pellet impact technique is that a parabolic shape of the bottomhole (Fig. 1) stipulates the direction of all following structural workings. Analysis of the conditions of well profile formation makes it safe to say that the formation of a peripheral part of the bottomhole is the subordinate factor determined by the proper operation of the devices. Efficient profile formation is possible only in terms of the introduction of additional units in a set of the hydromechanical drilling devices, which will help using certain technological methods. The aforementioned has resulted in the use of special units, introduced in the assemblies, for the formation of peripheral bottomhole part - mechanical rock-breaking organs, the following technological schemes: immediate processing of the peripheral bottomhole zone with steel rockbreaking pellets; formation of the well profile due to rock mass effected by fragments of rock-breaking pellets and even the rock itself; and combined scheme of breaking that includes the principles of the previous two schemes to a greater or lesser degree.

Consequently, the next stage of the research involved the determination of operational features of mechanical rockbreaking organs of modernized devices equipped with the pellets. Attention was paid to the analysis of functional dependence of the deepening rate of well bottomhole $u$ on physical condition of the breaking pellets (their material and property indices) and load value $C$ on the latter. The studies, whose results are given in Fig. 2, involved metal pellets of $d_{k}=5 \mathrm{~mm}$; the pellets were standard and thermally processed.

The data in Fig. 2 show the differences in the operational mechanics of rock-breaking pellets with different physical properties. If the thermally processed pellets are used, then almost proportional $u$ increase is observed along with the growing $C$ throughout the whole range. In terms of standard pellets, somewhat lower indices of well bottomhole $u$ deepening are characteristic, and proportionality of growth for the latter is violated if $C>2.6 \mathrm{~N} / \mathrm{mm}^{2}$. Besides, visual inspection of the worked out standard pellets demonstrates the development of plastic deformations in them, which is seen in the deviation of their shape from the spherical one. Thus, more detailed stud-

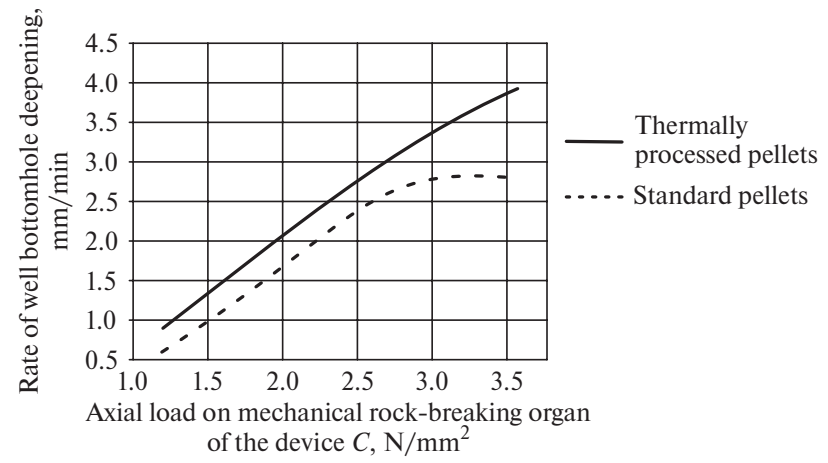

Fig. 2. Mechanics of the operation of different (in physical properties) rock-breaking pellets on the modeled well bottomhole ies are required to solve the problem of giving the breaking pellets certain physical properties.

The studies were carried out for the conditions of finegrained granites; rotation frequency of a rock-breaking organ was $n=260 \mathrm{~min}^{-1}$.

Stable conditions to break rock mass of a peripheral share of the well bottomhole in terms of the structural schemes of modernized hydromechanical devices are possible only under conditions of reliable location and keeping of the pellet within a special-purpose rock-breaking organ - ring, and direction of the pellets under its butt-end area.

Due to the mentioned reasons, further studies were aimed at specifying the effect of peculiarities of structural design of seats and butt-end area of the ring, and technological modes of operations of the latter. The studies involved rock-breaking rings with relatively smooth surface of a seat and butt-end area; in other case, contact surfaces of the seat and butt-end area were rough (with notches). The study results are represented in Fig. 3.

The data in Fig. 2 show the unambiguity of the effect of rough contact surface of the ring seats and butt-end area on the indices of rates of well bottomhole deepening $u$. While using the rings with rough contact surface, all other things being equal, it is possible to reach higher $u$ indices comparing to the operation of standard rings. The indicated fact is the result of the increasing reliability of contacting and torque transferring for the pellets by the rough surface of the ring and seat. Gradual $u$ increase in time for the rings with smooth contact surfaces is the result of the fact that the pellet surface acquires the distinct roughness. Some $u$ fluctuations in time for the rings with rough contact surfaces can be explained by periodic contamination of relief irregularities of the surfaces by the rock breaking products.

The studies were performed for the conditions of largegrained granites. Rotation frequency of a rock-breaking organ was $n=260 \mathrm{~min}^{-1}$; axial load was $C=3 \mathrm{~N} / \mathrm{mm}^{2}$ of the butt-end area of the rock-breaking organ.

Conditions of well profile formation may be implemented not only by the action of pellets on the rock mass but also by the cutting and wearing effect of their fragments, whose formation is connected with the deformation processes of contact interaction in the "rock-breaking organ - pellet - rock mass" system and use of brittle breaking materials. That was the reason to study the nature of the operation of cast iron pellets within the well bottomhole. Fig. 4 demonstrates the research results.

Development of the brittle-material pellet (Fig. 4) can be divided conventionally into three stages. Stage one involves rapid increment of well bottomhole deepening $u$; stage two shows comparatively short-term stabilization of $u$ value; and stage three demonstrates slow $u$ decrease of almost down to the complete stoppage of the breaking process. The given sequence is also characterized by the considerable change in the state of breaking pellets. In terms of stage one, we can observe intense pellet splitting; stage two differs with the fact that the

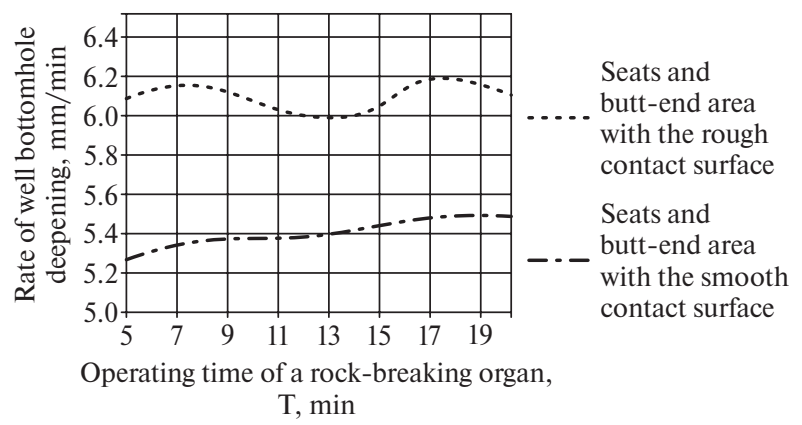

Fig. 3. Mechanics of the operation of rock-breaking rings with different state of contact surface of seats and butt-end area 


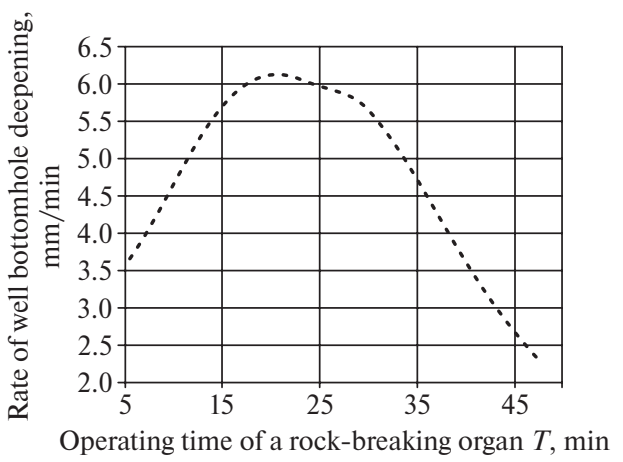

Fig. 4. Mechanics of the operation of rock-breaking pellets made from brittle materials in terms of the modeled well bottomhole

pellets have maximum abrasive properties at the expense of bared sharp edges; and stage three is connected with gradual blunting of cutting faces and further splitting of pellet fragments. Moreover, it should be noted that in terms of their breaking properties, cast iron pellets are highly competitive with the steel ones (in the context of the materials under study); in some cases, they are even better than the indices of the latter in terms of $u$ parameter. Thus, under conditions of both rational selection of the material for pellets and technological modes of the operation of hydromechanical devices, it is possible to reach the required indices of well deepening.

The conducted research has also proved the expediency of the design of a hydromechanical device, proposed by the specialists of the Department of OGED of Dnipro University of Technology, which contains a case 1 with a flow device 2 . The efficient formation of a peripheral zone of the well bottomhole is possible at the expense of action of pellets fragments 3 on the rock mass; the pellets are located and kept in a special rockbreaking organ 4 in the form of matrix, which bottomhole area is porous in its structure 5 (Fig. 5) [20].

Basing on the data that in terms of the proposed device, basic scheme of the formation of a peripheral zone of well bottomhole is selected to be the cutting and wearing action of pellets fragments on the rock mass, we can state the following: the indicated process will be stable only if we stick to certain conditions concerning the maintenance of rational values of axial load $C$ on the butt-end area of a rock-breaking organ. These are the methods for the implementation of the proposed statement which are to be studied further.

Fig. 6 contains generalized data as for the clarification of the mechanism of effect of values $C$ on the boundary attainable values of the well bottomhole deepening $u$.

While analyzing the data in Fig. 6, we can make the following conclusions: for brittle-material pellets, there is a certain rather narrow range of rational values of axial load $C$ on the butt-end share of a rock-breaking organ, in terms of which $u$ has its maximum indices for a specific case of the geological

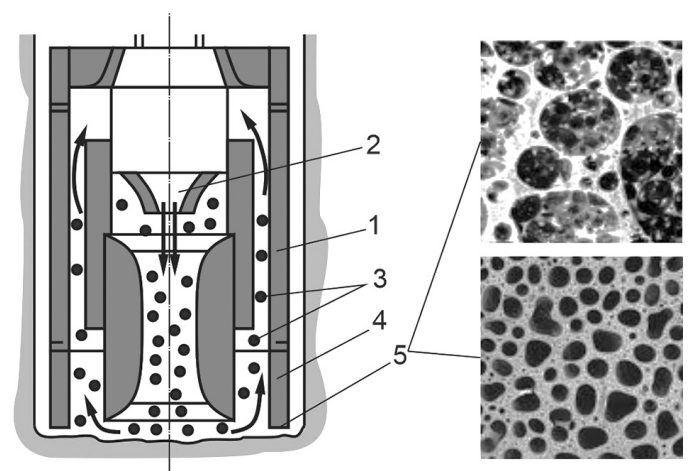

Fig. 5. Bottomhole share of a hydromechanical drilling device [20]

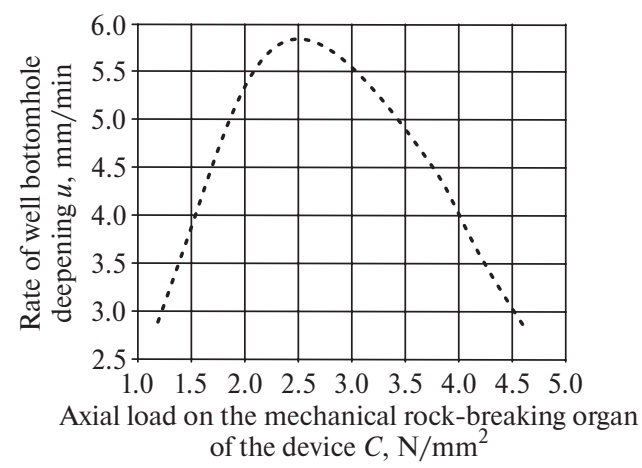

Fig. 6. Mechanics of the deepening of a peripheral share of the well bottomhole in terms of changeable values $C$

and technical conditions. In this context, qualitatively, relative to the physical state of breaking pellets, interval of the increase in rates of well bottomhole deepening $u$ may be characterized by the availability of unbroken pellets on the bottomhole; operation of the device with maximum $u$ values is accompanied by the start of splitting of the rock-breaking pellets; decrease in rate $u$ takes place along with the intense pellets breaking.

The studies were carried out in terms of coarse-grained granite; rotation frequency of rock-breaking organ was $n=$ $=260 \mathrm{~min}^{-1}, d_{k}=5 \mathrm{~mm}$.

Quite different breaking conditions of a peripheral share of the well bottomhole, in terms of the same technological data, are observed while using durable steel pellets; the data in Fig. 7 support the statement.

Dependence of the mechanics of the well bottomhole formation on the number of pellets $M$ operating on it (Fig. 7) may be explained by the redistribution of load $C$ between the pellets and changes in the processes of contact interaction of rockbreaking components of a bottomhole share of a hydromechanical device.

Increasing $M$ factors into the decreasing specific value of axial load $C$ on a certain pellet; however, in this context, conditions of pellets operation improve in general (Fig. 8). In terms of a small number of breaking pellets on the bottomhole, they are mostly prone to the actions of deformation processes. Moreover, the represented data show clearly the correspondence of each value $M$ to its maximum of deepening rate $u$; however, on average, the difference between its indices does not exceed 6-8\% with the assumption that growing $M$ results in the increasing consumptions of bottomhole power $N$. Thus, the following conclusion can be drawn: creation of the efficient conditions of rock breaking is connected with the required availability of a certain number of pellets $M$ on the well bottomhole; the number of pellets corresponds to the minimum of the consumption of bottomhole power $N$ and rational values of $u$ and $C$.

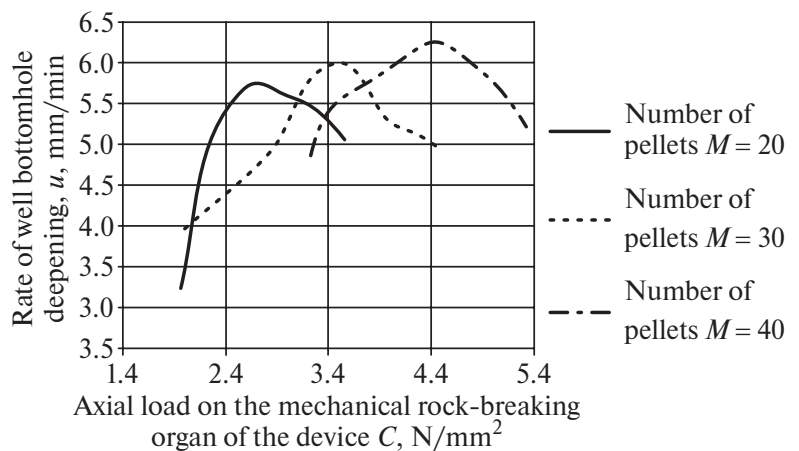

Fig. 7. Conditions of deepening for a peripheral share of the well bottomhole in terms of the variable number of breaking pellets $M$ 


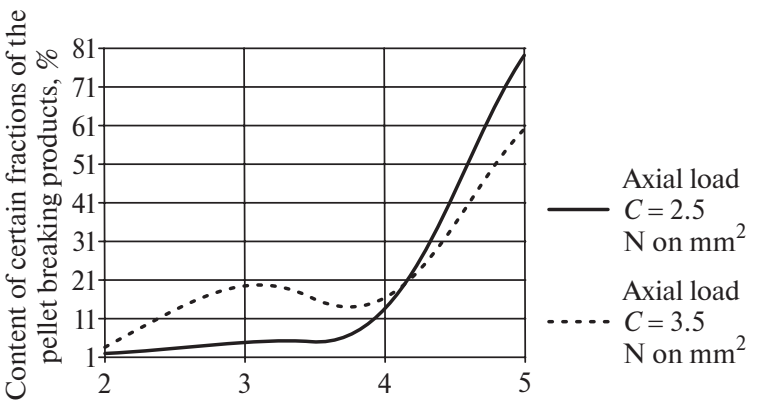

Typical size of the pellet breaking products $d$, mm

Fig. 8. Data on the granulometric composition of the pellet breaking products $\Delta$ in terms of changeable values $C$

Basing on the data represented in Fig. 8, it is possible to state the following: increase in axial load $C$ on a pellet results in the intensifying processes of deformation, wearing, and breaking of the pellets; moreover, a higher value $C$ corresponds to the increasing volumes of fine fractions $\Delta$. It may be noted qualitatively that: 1 ) in terms of lower value $C$, processes of deformation and wearing prevail over the breaking of pellets; 2) there is stable growth of abrasive action of the increased number of fine fractions of breaking products on the elements of bottomhole assembly of a hydromechanical drilling device.

The studies were carried out in terms of coarse-grained granites; rotation frequency of a rock-breaking organ was $n=$ $=260 \mathrm{~min}^{-1}, d_{k}=5 \mathrm{~mm}$.

The obtained research data also show the efficiency of the device operating according to the scheme of cutting and wearing action on the peripheral share of the well bottomhole while working just in terms of elastoplastic rocks characterized by relatively low hardness parameters

Thus, in terms of their optimal technical arrangement and technological run, the developed structural schemes of the devices for hydromechanical drilling may be recommended to be used in the corresponding geological and technical conditions where implementation of other methods is not expedient or limited.

Conclusions

1. According to the results of the review of literature sources, thorough analysis of the industrial and laboratory data made it possible to specify the main ways for improving the well hydromechanical technologies.

2 . The fundamental principles have been formulated concerning the process of design of such equipment schemes that will combine the most productive and efficient methods of the rock mass operations.

3. Studies on the operation of the improved hydromechanical drilling devices have identified numerous factors influencing their work. The following factors are among the most important ones, analyzed in this paper: a rational range of physical properties of rocks according to which proper technical and technological characteristics of the devices are selected; structural use of mechanical rock-breaking organs of the devices; and operating parameters of the drilling process.

4. Study on the peculiarities of hydromechanical drilling educed certain potential possibilities that can be the basis for the application of the represented method to perform a wide range of drilling operations in terms of the operating and projected mining enterprises.

5. Experimental and theoretical studies on the peculiarities of the implementation of hydromechanical drilling principles and operating characteristics of the modernized pellet impact devices should be continued in terms of elaboration of rational technical and technological solutions with the maximum consideration of mining and geological conditions of a specific site.
Acknowledgements. This research was partially supported by Dnipro University of Technology (Ukraine) and Technical University of Kosice (Kosice). We thank our colleagues from our institutions, who provided the insight and expertise that greatly assisted the research.

\section{References.}

1. Koroviaka, Ye., Pinka, J., Tymchenko, S., Rastsvietaiev, V., Astakhov, V., \& Dmytruk, O. (2020). Elaborating a Scheme for Mine Methane Capturing While Developing Coal Gas Seams. Mining of Mineral Deposits, 14(3), 21-27 https://doi. org/10.33271/mining 14.03.021.

2. Alekseev, V.I. (2013). The beetles (Insecta: Coleoptera) of Baltic amber: the checklist of described species and preliminary analysis of biodiversity. Zoology and Ecology, 23(1), 5-12. https://doi.org/10.1080/21658005.2013.769717.

3. Honchar, A., \& Fedoseienkov, S. (2016). Geo- and hydroacoustic complex as a study of interconnection between processes in waters and bottom sediments. Geodynamics, 21(2), 101-108. https://doi.org/10.23939/jgd2016.02.101.

4. Khomenko, O. Ye., Sudakov, A.K., Malanchuk, Z.R., \& Malanchuk, Ye.Z. (2017). Principles of rock pressure energy usage during underground mining of deposits. Naukovyi Visnyk Natsionalnoho Hirnychoho Universytetu, (2), 34-43.

5. Kornivenko, V.Ya., Malanchuk, E.Z., Soroka, V.S., \& Khrystyuk, A. O. (2018). Analysis of the existent technologies of amber mining. Resources and resource-saving technologies in mineral mining and processing, 209-232.

6. Li, D. (2014). Underground hydraulic mining of thin sublayer as protective coal seam in coal mines. International Journal of Rock Mechanics and Mining Sciences, (67), 145-154. https://doi.org/10.1016/j.ijrmms.2014.01.014.

7. Malanchuk, Ye., Korniienko, V., Moshynskyi, V., Soroka, V., Khrystyuk, A., \& Malanchuk, Z. (2019). Regularities of Hydromechanical Amber Extraction from Sandy Deposits. Mining of Mineral Deposits, 13(1), 49-57 https://doi. org/10.33271/mining13.01.049.

8. Malanchuk, Z., Korniienko, V., Malanchuk, Ye., Soroka, V., \& Vasylchuk, O. (2018). Modeling the formation of high metal concentration zones in man-made deposits. Mining of Mineral Deposits, 12(2), 76-84. https://doi.org/10.15407/ mining12.02.076.

9. Malanchuk, Z., Korniyenko, V., Malanchuk, Y., \& Khrystyuk, A. (2016). Results of experimental studies of amber extraction by hydromechanical method in Ukraine. EasternEuropean Journal of Enterprise Technologies, 3(10(81)), 24-28. https://doi.org/10.15587/1729-4061.2016.72404.

10. Malanchuk, Z., Malanchuk, Y., Korniyenko, V., \& Ignatyuk, I. (2017). Examining features of the process of heavy metals distribution in technogenic placers at hydraulic mining. Eastern-European Journal of Enterprise Technologies, 1(10(85)), 45-51. https://doi.org/10.15587/17294061.2017.92638.

11. Walter Henry Jeffery (2015). Deep Well Drilling: The Principles and Practices of Deep Well Drilling, and a Hand Book of Useful Information for the Well Driller. Palala Press. ISBN10: 1340771675. ISBN-13: 978-1340771676.

12. Biletskyi, V.S. (Ed.) (2013). Small Mining Encyclopedia (Vols. 1-3). Donetsk: Skhidnyi Vudavnychyi Dim. ISBN $978-$ 966-317-156-2.

13. Walter Henry Jeffery (2018). Deep Well Drilling: The Principles and Practices of Deep Well Drilling, and a Hand Book of Useful Information for the Well Driller. Franklin Classics Trade Press (19 Oct. 2018).

14. Forest John Swears Sur (2013). Oil prospecting, drilling and extraction. Nabu Press; Primary Source ed. edition (Oct. 3, 2013). 15. Davidenko, A. N., \& Ignatov, A. A. (2013). Abrasive-mechanical percussion well drilling. Dnipropetrovsk: Natsionalnyi Hirnychyi Universytet.

16. Davidenko, A. N., Ratov, B.T., Pashchenko, A.A., \& Ignatov, A.A. (2018). Effect of hydrostatical pressure on abrasive- 
mechanical well drilling. Almaty: Kaspiyskiy Obshchestvennyy Universitet.

17. Kovalyov, A. V., Ryabchikov, S. Ya., Isaev, Ye. D., Aliev, F. R., Gorbenko, M.V., \& Strelnikova, A. B. (2015). Designing the ejector pellet impact drill bit for hard and tough rock drilling. IOP Conferense Series: Earth and Environmental Science, (24), 1-6. https://doi.org/10.1088/1755-1315/24/1/012016.

18. Kovalyov, A.V., Ryabchikov, S. Ya., Isaev, Ye.D., Aliev, F. R., Gorbenko, M. V., \& Baranova, A. V. (2015). Pellet impact drilling operational parameters: experimental research. IOP Conference Series: Earth and Environmental Science, (24), 1-8. https://doi.org/10.1088/1755-1315/24/1/012015.

19. Marc Borremans. (2019). Pumps and Compressors. John Wiley \& Sons Ltd. https://doi.org/10.1002/9781119534112. fmatter.

20. Ihnatov, A. O., \& Viatkin, S. S. (2013). Pellet impact device for well drilling (UA Patent No. 102708). Ukrainskyi Instytut Intelektualnoi Vlasnosti (Ukrpatent). Retrieved from https:// base.uipv.org/searchINV/search.php?action=viewdetails\&Id Claim=189992.

\section{Геологічні й гірничотехнічні особливості реалізації принципів гідромеханічного буріння}

\section{А. О. Ігнатов ${ }^{1}$, С.А. Коровяка ${ }^{1}$, Ян Пінка ${ }^{2}$, B. О. Расивєтаєв ${ }^{1}$, О. О. Дмитрук ${ }^{1}$}

1 - Національний технічний університет «Дніпровська політехніка», м. Дніпро, Україна, e-mail: ignatov.a.a@ $\underline{\text { nmu.one }}$

2 - Кошицький технічний університет, м. Кошице, Словацька Республіка, e-mail: jan.pinka@tuke.sk

Мета. Обгрунтування конструктивних рішень в окремих вузлах модернізованих гідромеханічних пристроїв i визначення раціональних технологічних режимів їх роботи у конкретних геолого-технічних умовах. Пропозиції зі споруджування свердловин шляхом розроблення та впровадження прогресивних методів і прийомів.

Методика. Дослідження особливостей роботи модернізованих пристроїв гідромеханічного буріння на прикладі руйнування гірських порід виконано із застосуванням сучасних методів аналітичного аналізу та експериментальних досліджень, зокрема, шляхом використання методів математичного й фізичного моделювання, методик моделювання та обробки результатів досліджень у середовищі SolidWorks та ін., контрольно-вимірювальних приладів і матеріалів. Процес розв'язання задач оптимального планування експерименту поділявся на чотири етапи: складання моделі, що планувалась; підготовка необхідних вихідних даних; розрахунок моделі; отримання та обробка результатів. Протікання свердловинних породоруйнівних процесів моделювалося на спеціальному лабораторному стенді, обладнаному контрольно-вимірювальним блоком (витратомір, манометр, тахометр, координатник).

Результати. Визначені основні шляхи вдосконалення свердловинних гідромеханічних технологій. Сформульовані засадничі положення процесу проектування конструктивних схем пристроїв, що реалізовують такі способи руйнування, які комбінують у собі найбільш продуктивні та ефективні методи дії на порідний масив. Встановлена низка факторів, характерних для реалізації свердловинних гідромеханічних технологій, зокрема: раціональний діапазон фізичних властивостей гірських порід, відповідно до якого підбираються техніко-технологічні характеристики пристроїв; фізичні властивості руйнівних куль; конструктивне виконання механічних породоруйнівних органів пристроїв; режимні параметри процесу буріння. Доведено, що розроблені конструктивні схеми пристроїв гідромеханічного буріння, за оптимального технічного виконання й технологічного відпрацювання, можуть бути рекомендовані до застосування у відповідних геолого-технічних умовах, де реалізація інших методів нераціональна або обмежена.

Наукова новизна. Утворення периферійної частини вибою є підлеглим чинником, визначуваним самим виконанням пристроїв; ефективне профілеутворення можливе тільки за рахунок уведення до складу пристрої гідромеханічного буріння додаткових вузлів, що дозволяють застосування певних технологічних методів і прийомів.

Практична значимість. Отримані результати лабораторних й аналітичних досліджень є базовими для проектування режимних параметрів процесу поглиблення свердловини за рахунок використання гідромеханічних пристроїв. Дані з вивчення вибійних робочих процесів гідромеханічних технологій є вихідними положеннями для обгрунтування конструктивних і технологічних параметрів модернізованих кулеструминних пристроїв.

Ключові слова: гідромеханічне буріння, свердловина, промивальна рідина, гірська порода, струминний апарат, вибій

\section{Геологические и горнотехнические особенности реализации принципов гидромеханического бурения}

\author{
А.А. Игнатов ${ }^{1}$, Е.А. Коровяка ${ }^{1}, Я_{н}$ Пинка ${ }^{2}$, \\ B. А. Расиветаев ${ }^{1}$, Е. А. Дмитрук ${ }^{1}$
}

1 - Национальный технический университет «Днепровская политехника», г. Днепр, Украина, e-mail: ignatov.a.a@nmu.one

2 - Кошицкий технический университет, г. Кошице, Словацкая Республика, e-mail: jan.pinka@tuke.sk

Цель. Обоснование конструктивных решений в отдельных узлах модернизированных гидромеханических устройств и определение рациональных технологических режимов их работы в конкретных геолого-технических условиях. Предложения по сооружению скважин путем разработки и внедрения прогрессивных методов и приемов.

Методика. Исследование особенностей работы модернизированных устройств гидромеханического бурения на примере разрушения горных пород выполнено с применением современных методов аналитического анализа и экспериментальных исследований, в частности путем использования методов математического и физического моделирования, методик моделирования и обработки результатов исследований в среде SolidWorks и др., контрольно-измерительных приборов и материалов. Процесс решения задач оптимального планирования эксперимента делился на четыре этапа: составление модели, планирование; подготовка необходимых исходных данных; расчет модели; получение и обработка результатов. Протекание скважинных породоразрушающих процессов моделировалось на специальном лабораторном стенде, оборудованном контрольно-измерительным блоком (расходомер, манометр, тахометр, координатник).

Результаты. Определены основные пути совершенствования скважинных гидромеханических технологий. Сформулированы основные положения процесса проектирования конструктивных схем устройств, реализующих такие способы разрушения, которые комбинируют в себе наиболее производительные и эффективные методы воздействия на породный массив. Установлен ряд фак- 
торов, характерных для реализации скважинных гидромеханических технологий, в частности: рациональный диапазон физических свойств горных пород, согласно которому подбираются технико-технологические характеристики устройств; физические свойства разрушительных шаров; конструктивное исполнение механических породоразрушающих органов устройств; режимные параметры процесса бурения. Доказано, что разработанные конструктивные схемы устройств гидромеханического бурения, при оптимальном техническом исполнении и технологической отработке, могут быть рекомендованы к применению в соответствуюших геолого-технических условиях, где реализация других методов нерациональна или ограничена.

Научная новизна. Образование периферийной части забоя является подчиненным фактором, определяемым самим исполнением устройств; эффективное профилеобразование возможно только за счет введения в состав устройств гидромеханического бурения дополнительных узлов, позволяющих применение определенных технологических методов и приемов.

Практическая значимость. Полученные результаты лабораторных и аналитических исследований являются базовыми для проектирования режимных параметров процесса углубления скважины за счет использования гидромеханических устройств. Данные по изучению забойных рабочих процессов гидромеханических технологий являются исходными положениями для обоснования конструктивных и технологических параметров модернизированных шароструйных устройств.

Ключевые слова: гидромеханическое бурение, скважина, промывочная жидкость, горная порода, струйный аппаpam, забой

Recommended for publication by D. L. Kolosov, Doctor of Technical Sciences. The manuscript was submitted 09.07.20. 